\title{
Apontamentos sobre o texto teatral contemporâneo
}

\author{
Sílvia Fernandes
}

ualquer espectador ou leitor mais assíduo de dramaturgia contemporânea constata facilmente sua diversidade. Construída segundo as regras do playwriting ou como storyboard de cinema, estruturada em padrōes de ação e diálogo ou a partir de monólogos justapostos, tratando de problemas atuais de forma realista ou metaforizando grandes temas abstratos, hoje a peça de teatro desafia generalizaçôes. A diversidade da produção chega a ponto de levar um pesquisador da envergadura de Patrice Pavis a definir o texto teatral pelo critério elocutório. Segundo o teórico francês, atualmente texto de teatro é tudo aquilo que se fala em cena (Pavis, 1982, p. 140). O que parece um exagero de simplificação encontra eco no encenador americano Richard Schechner, para quem drama é tudo que o escritor escreve para a cena, e se opóe a script, o roteiro que serve como mapa de uma determinada produção (Schechner, 1988, p. 85).

Parece evidente que essas definiçōes pragmáticas resultam dos problemas para distinguir o texto teatral de hoje, quando as fronteiras do drama alargaram-se a ponto de incluir romances, poemas, roteiros cinematográficos e até mesmo fragmentos de falas esparsas, desconexas, usados apenas para pontuar a dramaturgia cênica do diretor ou do ator. Diante dessa situação, não é de estranhar que uma das principais tarefas do estudioso do texto teatral contemporâneo seja distinguir seu objeto. Pois tudo o que aparecia até o final do século XIX como marca inconfundível do dramático, como o conflito e a situação, o diálogo e a noção de personagem, torna-se condição prescindível quando os artistas passam a usar todo tipo de escritura para eventual encenação, na tentativa de responder às exigências de tema e forma deste final de século.

Talvez um olhar mais atento possa distinguir nas formas híbridas do texto teatral contemporâneo a necessidade de expressão de assuntos que os modelos históricos não conseguem conter. A hipótese é reforçada pela leitura do já clássico Teoria do drama moderno, de Peter Szondi. A perspicaz análise de Szondi mostra que a noção a-histórica de texto leva à suposição de que uma mesma forma dramática pode ser usada em qualquer época, para a construção poética de qualquer assunto. Defensor da posição dialética, o teórico alemão percebe, ao contrário, uma equivalência entre forma e conteúdo, com a forma concebida como uma precipitação do conteúdo (como quer Adorno), onde a temática nova funciona como um problema para a antiga moldura formal.

Sílvia Fernandes é professora do Departamento de Artes Cênicas da ECA-USP. 
$\mathrm{Na}$ época em que escreve, meados da década de 1950, Szondi constata que as peças compostas com diálogos trocados entre os personagens, como numa conversação quotidiana, são incapazes de expressar as novas contradições da realidade. E localiza a crise da forma dramática muito antes, por volta de 1880 , quando a crescente complexidade das relações sociais já não cabe no mecanismo do drama absoluto, que se estrutura a partir das relações intersubjetivas dos personagens. Não é de estranhar que, depois dessa crise, o drama seja cada vez mais contaminado por procedimentos épicos e escape à lógica intersubjetiva que funda a mimese teatral. A forte presença das técnicas analíticas na construção do texto teatral contemporâneo talvez indique que a diegesis seja o modo mais eficaz de representar os "estados de coisas" a que Benjamin se refere quando analisa o teatro épico brechtiano ${ }^{1}$.

A dramaturgia pós-dramática pode ser considerada uma das etapas mais recentes do texto teatral narrativo. Hans-Thies Lehmann, que cunhou o termo ao analisar as peças de Heiner Müller, observa que no limite essa dramaturgia prescinde do conflito, do diálogo, do personagem e da ação (Lehmann, p. 99). De fato, o leitor ou o espectador de Müller percebe em seus textos mais radicais um processo de desdramatização levado a extremos. Quartett, Medeamaterial ou mesmo Hamletmachine são verdadeiros tratados de argumentação, onde o personagem expõe seus enunciados de modo arbitrário, através de longos monólogos que impedem a troca dialógica e imobilizam o desenvolvimento da suposta fábula que, aliás, nem chega a ser definida pelo dramaturgo. No caso desse tipo de escritura dramática, como o assunto não é claro e o enredo não existe, o resultado é o esmaecimento do conteúdo, como observa
Fredrik Jameson em relação a outro contexto. $\mathrm{O}$ procedimento leva à diluição relativa do referente histórico, o que Jameson tenta explicar pela incapacidade que o artista contemporâneo teria de olhar o presente, um mundo extremamente complexo e cada vez mais difícil de mapear (Jameson, 1996, p. 51).

De qualquer forma, como sucessor de Brecht no Berliner Ensemble, Müller sempre alimentou a contradição entre a forma fragmentária, com potentes descrições de imagem, e os traços alusivos aos momentos traumáticos da história alemã deste século. É evidente que o horror nazista e a repressão estalinista permanecem como alegoria incômoda em quase todas as suas peças. Mesmo no caso de Quartett, baseada nas relações perigosas de Choderlos de Laclos, a rubrica inicial sugere um "bunker depois da terceira guerra mundial" onde se movimentam as figuras movediças de Valmont e Merteuil, trocando constantemente de papel como se fossem meras projeçōes do narrador. Essa identidade frágil força o espectador ou leitor a olhar os personagens como meras funções de enunciação e não mais como sujeitos com autonomia ficcional suficiente para lhes permitir ser agentes de um conflito dramático (Pavis, 1990, p. 93). Corroborando essa impressão, Stephen Watt menciona a subjetividade migratória como característica básica do drama mais recente, em que a identidade humana é marcada em termos de horizontalidade, e liga-se a travessias territoriais e ocupações temporárias de espaço, constituindo-se em termos bastante diferentes daqueles que enformam os modelos tradicionais de construção de personagem, mais próximos do aprofundamento vertical (Watt, 1998, p. 70).

De qualquer forma, Fernando Peixoto considera a posição fronteiriça da dramaturgia

1 "O teatro épico não reproduz, portanto, os estados de coisas, mas tem sobretudo que descobri-los. A descoberta dos estados de coisas se completa por meio da interrupção do curso dos acontecimentos” (Benjamin, 1969, p. 11). 
de Müller como um momento de síntese, pois mostra a firmeza ideológica revestida de perplexidade e a reflexão consciente sobre o processo histórico, o questionamento do significado e da prática da revolução e a discussão do socialismo postos em tensão pelo debate sobre a ética individual (Peixoto, 1987, p. xv). Nesse turbulento espectro temático, não é de estranhar que o conflito seja substituído pela idéia de catástrofe, e em lugar de opor os protagonistas, oponha o narrador ao mundo narrado.

No aspecto estrutural, pode-se considerar a dramaturgia de Müller como o correlato literário de um tipo de encenação freqüente no princípio dos anos 80 , criado especialmente por artistas da vanguarda formalista americana, como Bob Wilson e Richard Foreman, e no caso brasileiro, por Gerald Thomas. Em certo sentido, os textos do autor alemão são a prova de que os dramaturgos não ficaram alheios às modificaçôes do espetáculo contemporâneo e parecem ter incorporado ao veículo literário os procedimentos criados por seus parceiros de cena, redefinindo assim os limites da textualidade dramática. Certamente não se deve ao acaso a parceria de Heiner Müller com Wilson nas encenaçōes de Hamletmachine e Quartett.

Michael Vanden Heuvel foi um dos primeiros teóricos contemporâneos a apontar o forte movimento da dramaturgia do período em direção à encenação, que agiu como fator de modificação das estruturas textuais. Para Heuvel, esse mecanismo permitiu ao texto incorporar a indeterminação e a dispersão características da performance dos encenadores mencionados, além de influenciá-la, pois os canais dramático e cênico sempre operaram como interfaces abertas (Heuvel, 1993, p. 19-20). As peças de Müller seriam um dos exemplos do processo formativo texto/cena deflagrado em conjunto, cujo grande precursor foi Samuel Beckett, e que envolveu outros criadores, como o Wooster Group e
Sam Shepard, para mencionar apenas os casos exemplares.

O movimento não é novo. Como lembra Anne Ubersfeld, a dramaturgia sempre foi escrita contra ou a favor do "objeto-teatro" a que se dirigia (Ubersfeld, 1981, p. 14). A forma dramática, além de expressar um sentimento de época, sempre revelou uma prática cênica, um tipo de desempenho e uma determinada imagem da representação. A qualidade do espaço, o estilo de atuação e o modelo de fábula que o teatro estava apto a contar sempre foram fatores determinantes da escritura do dramaturgo. A diferença, sentida numa parcela da dramaturgia recente, é que esta aparentemente esqueceu as preocupações com a ação dramática, escrita para ser atualizada pelo espetáculo. Talvez a resposta dos dramaturgos à escritura autoral dos encenadores tenha sido uma dramaturgia não dramática, sem ação, que em última instância é autônoma. Pode ser lida como poema, depoimento ou relato. Nada em sua conformação revela a famosa incompletude literária, os "buracos" a que Ubersfeld se refere quando destaca a necessária passagem do literário para o cênico.

Talvez o exemplo mais radical dessa dupla autonomia - da escritura dramática e da escritura cênica - sejam as peças de Heiner Müller supostamente encenadas por Bob Wilson. A verdade é que as montagens de Müller por Wilson tinham pouca semelhança com o que se entende por encenar um texto dramático. $\mathrm{O}$ artista americano gravava a íntegra das peças do dramaturgo e as exibia ao público como trilha sonora da escritura cênica. $\mathrm{Na}$ realidade, o que se via no palco era a justaposição do texto do dramaturgo no espaço sonoro e do texto do encenador no espaço cênico, literatura e teatralidade justapostas para criar um sentido aberto, que cabia ao espectador completar ${ }^{2}$.

Talvez essa tenha sido uma das mudanças mais radicais da relação texto/cena no teatro

2 Para uma interessante análise das montagens, ver Maurin, 1998. 
contemporâneo. Para entendê-la, não é preciso voltar à discussão sobre a natureza literária ou teatral do texto dramático. Jiri Veltruský, teórico da escola de Praga, considera a discussão inútil. Observa que sem dúvida o drama é uma obra literária e, enquanto tal, pode ser simplesmente lido ou usado como componente da performance, como faz Bob Wilson com os textos de Müller. A diferença está no tipo de teatro que se pratica e, em última instância, vai determinar a escolha e o uso que se faz do texto. Algumas formas teatrais contemporâneas, por exemplo, preferem os textos líricos e narrativos ao drama, pois pretendem que a escritura cênica entre em relação com a literatura como um todo, e não apenas com o gênero dramático (Veltruský, 1976, p. 95).

Richard Schechner retoma, em certo sentido, a discussão de Veltruský, quando distingue dois tipos de texto de teatro. O texto performático (performance text) é indissociável da representação e existe apenas enquanto materialização cênica relacionada a outros componentes da escritura teatral. A representação lhe dá suporte e coerência, e é apenas como parte dela que pode fazer sentido. Exatamente por isso o texto performático é fragmentado, heterogêneo, múltiplo, e seria incoerente tentar analisá-lo enquanto obra literária, pois depende dos outros sistemas cênicos para se realizar. É verdade que pode ser transcrito, mas apenas como partitura mínima da representação, pois depende da intervenção de outros elementos para compor a totalidade da escritura cênica. Schechner opõe o texto performático a algo que chama simplesmente de texto (text), cuja existência extra-cênica considera perfeitamente legítima, pois precede a representação e sobrevive a ela enquanto obra literária autônoma. $\mathrm{O}$ encenador americano associa os dois tipos de texto às tradições te- atrais do ocidente e do oriente e define o texto performático recorrendo ao teatro Nô. "O drama Nô não existe enquanto conjunto de palavras que serão, em seguida, interpretadas pelos atores, mas enquanto um conjunto de palavras inextricavelmente unidas à música, aos gestos, à dança, aos diferentes modos de interpretação teatral, aos figurinos" (Schechner, 1991, p. $247)^{3}$.

Partindo da distinção de Schechner, Josette Féral procura relativizá-la. Em primeiro lugar, enfatiza a existência de diferentes tipos de texto performático, dependendo da natureza e do modo de inserção no espetáculo. Para Féral, ainda que muitos deles sejam incompletos, fragmentados, heterogêneos, sem linha narrativa, e seu sentido não se ligue à lógica do discurso literário, mas à combinatória de elementos cênicos em meio aos quais são apresentados, outros mantêm a linearidade narrativa sem deixar de permitir um discurso cênico múltiplo. A ensaísta afirma que, nos dois casos, a constante é a dependência dos textos à totalidade da encenação, pois ambos fazem sentido apenas em relação aos elementos da representação com que dialogam. Adotando uma perspectiva histórica, considera o texto e o texto performático como os dois pólos entre os quais a encenação contemporânea oscila, com o teatro dos anos 60 e 70 escolhendo de preferência o segundo como base da representação. Acredita que numerosos encenadores do período preferiram trabalhar com textos não criados originariamente para o palco por julgarem que os excertos de romances, poemas ou depoimentos favoreciam uma maior liberdade criativa. Continuando sua análise, Féral observa que o teatro dos anos 90 retornou ao texto literariamente autônomo, eleito como matriz para a criação dos espetáculos. Mas adverte que é preciso ver nessa polari-

3 A tradução brasileira publicada pela Hucitec opta por "texto da representação", mas preferi o neologismo "texto performático" para distinguir "performance text" do conceito de "texto espetacular", que define a escritura integral do espetáculo, e muitas vezes é traduzido como texto da representação ou texto cênico. 
dade não uma relação de exclusão, que considera empobrecedora, mas antes um movimento de complementaridade. Aproximando-se de Veltruský, a ensaísta sugere que a opção preferencial por um ou outro tipo de texto, ou por ambos, depende de fatores exteriores, como ideologias e estéticas dominantes, associados a questóes ligadas ao percurso criativo do artista. Ainda que não discorde de Schechner de forma clara, Féral sugere que não é a presença ou a ausência de um texto performático que vai definir o tipo de encenação. E, pode-se acrescentar, não é isso que determina o uso que o encenador faz do texto. São as modalidades de integração do texto aos outros elementos da representação que permitem dizer a que categoria a encenação pertence e de que forma ela trata o texto, performático ou não.

Para corroborar suas conclusões, Josette Féral cita o encenador canadense Robert Lepage, responsável pela autoria cênica integral das produções que dirige, quer faça uso de textos ou textos performáticos, alternadamente ou de forma simultânea. Menciona como exemplo os espetáculos Les Aiguilles, l'Opium e Elseneur, considerando este último bastante fiel ao Hamlet de Shakespeare (Féral, 1999). No caso brasileiro, sem dúvida é Antunes Filho quem mais se aproxima dessa alternância, o que pode ser conferido nas montagens de Drácula e Gilgamesh e nas encenaçôes de Nélson Rodrigues, do Macbeth de Shakespeare (Trono de Sangue) e, mais recentemente, das Troianas de Eurípides (Fragmentos Troianos). Também Enrique Diaz faz opção alternada por um ou outro tipo de texto, quando cria $A$ bao a $Q u$ ou encena $A$ Morta e $O$ rei da vela de Oswald de Andrade, sem que isso influencie de forma substancial sua autoria cênica.
As observações de Veltruský, Schechner e Féral podem facilitar a mudança do foco de análise do texto teatral. Pois até bem pouco tempo a função precípua da peça de teatro era projetar uma ação dramática que a cena deveria atualizar. Sem dúvida foi Raymond Williams quem investigou as etapas decisivas dessa relação. Para definir sua abordagem, Williams vinculou teatral a dramático, medindo a teatralidade pela capacidade que a literatura teria de criar ação através dos diálogos ou de outros recursos disponíveis no veículo textual. Ao analisar por esse prisma o desenvolvimento histórico da forma dramática, constatou mudanças por volta do princípio do século, o mesmo período em que Szondi localizou a crise. Williams definiu a mudança a partir do momento em que autores dramáticos como Tchekhov passaram a escrever textos em que os diálogos se dissociavam da ação, transformada em algo que ele chama de comportamento, onde se consubstancia uma nítida separação entre fala e performance. Agora o texto dramático projeta uma "conversação provável” em que não há relação exata entre a organização das palavras e o método de falá-las. Nem é preciso dizer que a peça de Tchekhov abre espaço para uma interpretação sujeita a amplas variações. As constantes divergências do dramaturgo com Stanislavski a respeito da montagem de seus textos são mais uma prova da instauração da polifonia significante a que Bernard Dort se refere quando analisa o teatro contemporâneo ${ }^{4}$.

Entre outros motivos, é para ocupar o espaço aberto pelo texto que o encenador começa o lento trabalho de elaboração de uma escritura própria, iniciando o movimento de justaposição do texto cênico ao dramático, até que o primeiro adquira plena autonomia. Como observa

4 “The Seagull, by Chekhov", capítulo de Drama in performance em que Raymond Williams analisa o caderno de direção de Stanislavski para a montagem de A Gaivota, de Tchekhov, é um ótimo exemplo de elaboração do texto cênico paralelo, com descriçôes muito esclarecedoras. 
Williams em outro ensaio, a "repetida tensão entre dramaturgos e encenadores, tão marcante nesse século, é característica dos problemas da própria forma dramática. Isso fica especialmente claro nos movimentos de reforma literária que, concentrando-se nos problemas da fala dramática, menosprezaram os problemas básicos da ação dramática. Mudar a convenção da fala, mas não a outra convenção, é desintegrar uma forma que já tem seus métodos teatrais, e criar um hiato que a produção é forçada a preencher" (Williams, 1975, p. 407).

Ao preencher esse hiato, a encenação permitiu à dramaturgia completar o percurso de autonomia e de expurgo da ação dramática a que me referi anteriormente. E, por outro lado, também estimulou o movimento paralelo de incorporação da nova materialidade cênica. Nesse caso, a contaminação do drama pela cena contemporânea aconteceu especialmente através do uso de procedimentos literários que já não pretendiam construir uma ação dramática para ser atualizada pelo palco. Agora os dramaturgos procuravam incorporar a própria teatralidade ao texto, na tentativa de apropriar-se de tudo aquilo que na representação é especificamente cênico, essa "espessura de signos e sensaçôes" que Roland Barthes liga a uma espécie de "percepção ecumênica de artifícios sensuais, gestos, tons, distâncias, substâncias, luzes, que submerge o texto sob a plenitude de sua linguagem exterior" (Barthes, 1964, p. 41-2).

O resultado da apropriação da teatralidade pela dramaturgia mais recente é que o texto literário ganhou novo estatuto. $\mathrm{O}$ dramático ainda se conserva no modo de enunciação, na construção dos diálogos, monólogos ou narrativas e, algumas vezes, no desdobramento dos personagens. Mas a qualidade teatral deixa de ser medida pela capacidade de criar ação. Agora teatral pode ser apenas espacial, visual, expressivo no sentido da projeção de uma cena espetacular. Paradoxalmente, é teatral um texto que contém indicaçôes espaço-temporais ou lúdicas auto-suficientes. Os textos do dramaturgo francês Bernard-Marie Koltès, por exemplo. É inte- ressante observar como em suas peças a circulação da palavra auxilia a construção de estratégias espaciais complexas. $\mathrm{Na}$ solidão dos campos de algodão é uma "trans-ação" entre traficante e cliente onde o jogo de ataque e defesa é projetado através dos movimentos do diálogo. Sem utilizar uma única rubrica, Koltès consegue sugerir a imobilidade do primeiro e a movimentação do segundo através de um "motim verbal" que se desdobra no ritmo preciso das falas e nas passagens bruscas do discurso altamente retórico à linguagem cotidiana. $\mathrm{O}$ movimento do traficante em direção ao cliente e o recuo deste, na tentativa dúbia de negar e afirmar a intenção de compra, acabam projetando territórios de ação.

Jean-Pierre Ryngaert nota, com razão, que essa dança do desejo é falada, comentada e realizada no desdobramento da linguagem, de precisão quase maníaca, que em última instância é quem se encarrega de coreografar a tensão que une e opõe os personagens. Nesse percurso, o diálogo não exibe o desejo por meio do sentido das falas - de certa forma, trata-se de um encontro de trajetórias abstratas - mas por intermédio do elaborado sistema espacial que a palavra projeta, dando acesso ao prazer através da construção de uma rede imaginária de aproximações verbais (Ryngaert, 1998, p. 25-6). Como observa Anne Ubersfeld, todo o sistema espaço-temporal do texto é baseado nas isotopias desse movimento verbal de idas e vindas, que constrói uma coreografia repetitiva através da recorrência do mesmo vocabulário. Pode-se dizer que os argumentos do cliente ressoam nas falas do freguês como gestos, e a alternância de monólogos fluentes e diálogos lacônicos hibridiza as formas dramática e épica, ao mesmo tempo em que cria, pela alternância e variação, um intenso ritmo cênico (Ubersfeld, 1996, p. 196).

Michel Vinaver nota que os diálogos de Na solidão dos campos de algodão têm qualidade postiça e retórica, acentuada pela falta de ligação entre pergunta e resposta. $\mathrm{Na}$ verdade, as réplicas infladas são longos monólogos em que cada interlocutor fala até perder o fôlego, sem que nunca se tenha certeza a quem se dirige. Em 
lugar de responder, o antagonista geralmente retoma sua fala anterior, compondo um movimento musical de repetição/variação também presente em outro texto de Koltès, o Combate de negro e de cães. A situação inicial da peça é a de um homem que vem exigir de outro a restituição imediata de um corpo. A diferença de visões de mundo entre Alboury e Horn, o negro e o europeu, são demarcadas através dos territórios que as falas projetam quando o primeiro entra no campo do outro para reclamar seu direito. O interessante é que Koltès consegue figurar a temática de oposição entre culturas no eixo espacial projetado pela exuberância da vegetação tropical (a rubrica do primeiro segmento indica "atrás das buganvílias, no crepúsculo") oposta ao canteiro de obras. O principal tema da peça é exatamente a oscilação entre os territórios demarcados pelo dentro e o fora, o velho e o jovem, o branco e o negro, a Europa e a África. Pode-se dizer que os principais eixos temáticos ligam-se a essa oposição de espaços e, nesse sentido, é possível concluir que a ação dramática é a passagem de um território a outro, de uma situação espacial a outra, feita através do movimento físico/verbal dos personagens. Nessa forma de construção dramática, que Michel Vinaver considera uma "peça/paisagem" figurada pela aventura da palavra, a temática se cristaliza na projeção de espaços cênicos conflitantes, territórios inimigos "confragrados no passe de armas dos diálogos" de réplicas incisivas não tanto pelo conteúdo semântico, mas pela brutalidade física que produzem (Vinaver, 1993, p.47-82).

No momento em que um autor lança mão desses procedimentos para elaborar seus textos, outras dinâmicas de construção dramática estão em jogo. A atividade da palavra toma o lugar antes reservado à progressão da intriga. Dessa forma, o que Koltès concebe é uma micro-dramaturgia baseada em estratégias de diálogo feitas de figuras de ataque, de resposta, de esquiva, criando armadilhas que restabelecem uma perspectiva agonística, desta vez dentro da própria linguagem (id., ibid., p. 82).
Patrice Pavis vê nessa retomada do diálogo um indício da necessidade de reatar relações com o outro, mesmo que esse outro seja, como $\mathrm{Na}$ solidão dos campos de algodão, apenas um reflexo invertido. No combate entre o cliente e o freguês, percebe a vontade de restaurar a dialética da troca humana e, ao mesmo tempo, a necessidade de fazer com que o outro fale para "interpelar o mundo em suas certezas".

No entanto, é sintomático que os personagens de Koltès, apesar de estarem sempre em busca dos argumentos do interlocutor, pareçam questioná-lo sem esperança de resposta imediata. O que explica que os diálogos patinem nas réplicas infladas, parecendo girar em falso. Segundo Pavis, esse processo mostra a visão de mundo de um artista que perdeu a vontade de explicar ou compreender, "como se a questão do sentido, o da obra e o do mundo, tenha se tornado obsoleta”. Essa opiniāo não impede o teórico francês de constatar uma forte ligação da dramaturgia francesa contemporânea com a realidade, especialmente sensível nos textos de Koltès, em que a violência das grandes metrópoles pode explicar em parte a solidão existencial e a exclusão social dos personagens (Pavis, 1998).

A mesma violência e marginalidade reaparecem nos textos do dramaturgo brasileiro Dionísio Neto. O crítico Nélson de Sá vê no artista um estranho híbrido dos diretores José Celso Martinez Corrêa, Gerald Thomas e Antunes Filho, que Dionísio considera o principal responsável por sua formação (Sá, 1998, p. 444). A influência dos três encenadores pode explicar a clara incorporação de recursos cênicos a textos que trazem as marcas da teatralidade contemporânea tanto nas falas quanto na estrutura narrativa e fragmentária. A par disso, é visível a filiação do dramaturgo ao teatro de Zé Celso, de quem empresta a urgência de ser cronista do tempo. "Quero extrair poesia do homem contemporâneo, do português coloquial”, afirma em entrevista recente.

De fato, a violência da grande cidade brasileira explode no registro do submundo urbano e no tecido social esgarçado em cenas terminais 
em que marginais e artistas associam a discussão existencial ao crime, às drogas e à descrença. É o caso de Desembest@i, texto de 1996, que mostra adolescentes praticando crimes descritos em detalhes macabros, que lembram certas passagens do Roberto Zucco de Koltès.

Quanto à influência de Thomas, ela é visível em peças como Perpétua e sobretudo em Opus Profundum, justaposição de monólogos/ performances de três protagonistas do contemporâneo - um fotógrafo, um ator e um apaixonado pela imagem - que vomitam as visões sujas do imaginário urbano de fim de milênio. A "peça-show para atores, cantores e banda de rock" tem apenas dois diálogos finais, um deles a entrevista de um repórter com o ator de fama internacional que mal disfarça a voz onipresente do dramaturgo. Como nos trabalhos de Thomas, o texto combina essa ostentação da autoria à indicação, nas rubricas, de inserções de dança, música, cinema, mídias eletrônicas e virtuais, artes plásticas e moda, na conexão das muitas referências do imaginário do artista.

A despeito da inclusão dos vários intertextos da cultura contemporânea, o recurso estrutural mais interessante de Opus Profundum é o uso sistemático de sugestões de cena nos monólogos, com indicações de movimento e projeções de gesto contaminando as falas dos personagens. A impressão que se tem é a de um dramaturgo que consegue incorporar ao texto literário procedimentos de atuação experimen- tados com os grandes diretores de ator com quem trabalhou, como Antunes e Zé Celso. Mas a incorporação dessa dramaturgia do ator não acontece em forma de rubricas, o que em última instância reforçaria a dependência do texto à realização cênica. O que Dionísio parece adotar é um modelo textual específico, semelhante ao de Koltès, capaz de transformar os monólogos em performances de palavra 5 .

A partir dessas observações, é fácil concluir que na dramaturgia de Dionísio Neto prepondera o que Franco Ruffini chama de "cena do texto". O teórico italiano percebe, em qualquer texto de teatro, a convivência de dois componentes. $\mathrm{O}$ "texto do texto" é o elemento rígido, orientado, programado, que diz respeito ao conflito e à fábula, e tem como eixo o encadeamento da intriga. A "cena do texto", ao contrário, é representada pelo personagem e tudo que lhe diz respeito, incluindo as réplicas e microsituaçôes que se mantêm à margem do conflito e da fábula, dando passagem a certa imprevisibilidade e curso livre ao encenador e ao ator. Essa distinção permite avaliar como o texto de Dionísio tem pouco a ver com o encadeamento da intriga e a coerência das ações. E como deve muito à simultaneidade, ao ritmo, ao modo de compor as falas e o gesto, à projeção do espaço, mas também aos deslizamentos de sentido, à poesia das palavras, às surpresas de construção.

À primeira vista, não é o que acontece com as peças do dramaturgo paulista Fernando

5 Processo semelhante acontece em relação aos diálogos. Da mesma forma que as indicaçôes cênicas, eles são incorporados aos monólogos como fala direta, na repetição de um procedimento bastante comum na dramaturgia de Koltès, especialmente evidente no longuíssimo monólogo que é $A$ noite logo antes das florestas. Veja-se a esse respeito um trecho do monólogo de Opus Profundum que descreve uma batida policial: "Mão na cabeça! Mão na cabeça senão leva furo! Mas eu não fiz nada. Tá drogado, filho da puta. Tá com olho de drogado! Mas eu... Cala boca senão vai virar peneira pra São Pedro lavar roupa! Encosta na parede! Tá machucando. É pra machucar sua bicha. Sou filho de advogado. Pode ser filho do Papa! Tô limpo. Aí você tem certeza que vai ser ali. Pronto, chegou a sua hora. Valeu. E a Anna Stesia? Foda-se. Documento. Documento. Cadê o monza? Não sei de nada. Cê roubou monza, caralho. Tava andando indeciso. Tava procurando orelhão. Pascoale. Porra, foste tu que fotografou o Papa com as bicha evangélica? Te vi na televisão. Pascoale" (Neto, 1996). 
Bonassi. Semanticamente fortes, elas têm uma relação imediata, quase selvagem, com o real. O espectador ou leitor é atropelado pela pulsação contemporânea que explode no longo monólogo de Preso entre ferragens ou nos diálogos tensos e brutais de Um céu de estrelas, romance posteriormente adaptado para cinema e teatro. A narrativa clara torna as peças perfeitamente legíveis como obras literárias e mostra um autor que conhece bem a realidade do teatro, mas sabe escrever textos que não dependem do palco para existir. São autônomos enquanto ficção e projeção de uma cena imaginária.

A linguagem de Bonassi é arma de duplo corte que secciona a realidade social de classe média baixa e a solidão existencial das personagens, o impasse brasileiro e a dissolução moral do homem contemporâneo. Essa duplicidade permite que os efeitos de real, ou de autenticidade, estejam estreitamente associados e se alternem a recursos da mais radical teatralidade. Em Um céu de estrelas, por exemplo, o dramaturgo trabalha de forma aparentemente realista a história de um desempregado que invade a casa da noiva que o abandonou e comete todo tipo de violência, para acabar cercado pela polícia. No entanto, esse realismo sediado na Mooca convive com todo tipo de inverossimilhança assumida pelo dramaturgo - a polícia que chega sem ser chamada, o contexto social insuficiente, a frágil personagem da mãe, que nem nome tem, e reza no banheiro como coro passivo dos protagonistas. É visível que o acento local e a ambientação naturalista interessam ao dramaturgo, mas seu ponto de partida é um leitmotiv temático, geralmente a violência em todas as formas possíveis, incorporado a personagens comuns ou marginalizados.

Em As coisas ruins da nossa cabeça, Bonassi trabalha a mesma estrutura aparentemente realista, com diálogos plausíveis que opõem os personagens Lena e Vilela. Mas, como no texto anterior, aos poucos esses seres desajustados e isolados em um bar de estrada na Amazônia (que pelo tom do texto, poderia ser um deserto de Shepard) são colocados em situaçôes-limite, inverossímeis, mas dissimuladas em hiper-realismo. O contraste entre a plausibilidade dos diálogos e o absurdo da situação exposta - o tensionamento da violência até o limite, sem que se expliquem as razóes que levaram a ela é o tratamento de choque que Bonassi aplica à forma realista, cujo resultado é uma concentração dramática que se aproxima da estrutura da tragédia. Tragédia da falta de controle dos personagens sobre a ação que não compreendem e da qual não são sujeitos. Tragédia da falta de esperança que, como bem observa Jean-Claude Bernadet, coloca o texto na contracorrente de um tipo de mentalidade contemporânea, que só admite o desfecho reconfortante.

Esse caminho dramático fatalmente levaria Bonassi à alegoria, procedimento básico de construção de Apocalipse 1, 11, em que a personificação de idéias ganha o contraponto feroz do naturalismo anterior, e onde Talidomida do Brasil, a prostituta Babilônia e o Anjo Poderoso convivem com cenas desconcertantes de um negro espezinhado pelo preconceito racial. A analogia da violenta exclusão social brasileira com o Apocalipse de São João é nuclear para a concepção da peça, feita através de workshops coletivos com o Teatro da Vertigem e o encenador Antonio Araújo.

Desde o princípio dos trabalhos, Bonassi é levado para a sala de ensaios, integrando a criação do texto ao trabalho dos atores, que se guiam pelo risco do depoimento pessoal. Improvisações, vivências, visitas a locais de referência para ações e personagens e workshops breves são os instrumentos de dissecação temática escolhidos pelo elenco. Daí resulta a versão inicial do Apocalipse de João, em que o dramaturgo associa sugestóes poéticas, medos essenciais e julgamentos de mortos a seu costumeiro realismo cru.

Depois de concluir essa primeira versão do texto, em abril de 1999, Fernando Bonassi inicia a segunda etapa de trabalho. Agora o foco de criação é o espetáculo, ensaiado em oficinas públicas dirigidas pelo grupo. Paulatinamente, um novo texto cênico de atores e diretor vai sendo agregado às primeiras soluçôes, num movi- 
mento de idas e vindas feito pela dramaturgista, que se encarrega de facilitar a troca do autor com os atores e garante a presença coletiva na reescritura das cenas.

O novo processo, quase inaugural, leva a modificações sucessivas do roteiro. $\mathrm{O}$ mais importante a observar, no entanto, é que cada criador reage de forma independente aos estímulos do trabalho colaborativo. Enquanto Antônio Araújo cria uma ambiência particular, auxiliado pelo poderoso espaço do presídio, Bonassi projeta no texto soluções também cênicas - espaciais, gestuais, cinéticas - através de palavras que desenham sua própria visão do apocalipse. Vale a pena notar como essas projeções não se restringem às rubricas metafóricas, mas invadem as falas dos personagens, acabando por compor uma cena imaginária quase independente, como se o dramaturgo usasse a prática coletiva, os improvisos do elenco e as descobertas da pes- quisa de campo para a composição de um roteiro de falas, espaços e gestos ${ }^{6}$.

Na leitura pública da peça, realizada pelo grupo quase um ano antes da estréia, era visível a autonomia dessa cena de palavras. Nessa altura o espetáculo ainda não existia e a audição do texto limpo, sem a friç̧ão da teatralidade posterior, ressaltava o caráter das rubricas, que projetavam espaços cênicos diferentes daquele que o espectador encontraria mais tarde. A impressão era de que o dramaturgo, consciente do trabalho autoral de atores e encenador, usava o texto para criar sua própria cena imaginária, mais tarde contraposta à profusão barroca de Antonio Araújo7.

O dado diferencial do texto de Bonassi, paradoxalmente saído de um coletivo, é o ponto de vista singular que preserva. Como se intuísse que a polifonia do apocalipse só poderia ser composta por vozes dissonantes, as úni-

6 Como ilustração desse procedimento, é interessante reproduzir aqui a "Ambientação 3", que abre o prólogo da primeira versão do texto: "Nos corredores que levam ao espaço da própria cena, os espectadores verão diversos corpos pendurados por cordas, enforcados. Os corpos oscilam como pêndulos. Alguns deles, agonizando, ainda sofrem espasmos e emitem seus últimos ruídos roucos". Ou ainda a descrição da "Espelunca da besta", Ato 1, "A ascensão da Besta": "Acompanhamos João até o local do 'Último show da Besta'. Trata-se de um ambiente que remete às piores espeluncas, com umas poucas mesas. Num canto, uma TV exibe cenas de acidentes de automóveis, grandes enchentes e queimadas. Essas imagens são intercaladas por um letreiro com a inscrição: 'O tempo está próximo!' Um garçom de quinta categoria prepara o espaço, ajeitando mesas, enxugando copos num mesmo pano em que assoa o nariz. Numa das mesas, quatro jogadores promovem um carteado, fazendo um grande alarido" (Bonassi, p. 6, 26).

7 Veja-se, a esse respeito, "A quarta carta", lida no segundo ato da peça, "Queda de Babilônia": "Haja o que houver, a que tempo for, será a noite mais preta de todas as noites negras, em que os deuses das chances dormem pesadamente, e sobrevoam corvos insanos dos piores Demônios do Brasil, terra de contrastes e chacinas, convocando a face carcomida da morte violenta, dentes à mostra, quando os assassinos entram pro que der e vier, deixando cem gramas de alma no esgoto da covardia, contra homens desprezíveis cujas nucas explodem feito ovos e braços inúteis pedem clemência sob camas já tampas de sarcófago. Só mesmo cães assustados é que salvam-se, mascando genitálias" (Bonassi, p. 60). Lendo esse trecho, é inevitável pensar no conceito de hypotyposis, que Anne Ubersfeld empresta de Quintiliano, via Henri Morier, para referir-se à construção de micro-cenários de palavras, que contam histórias ou projetam quadros, por meio dos quais o espectador cria imagens sem o auxílio de estímulos visuais. Segundo Ubersfeld, uma das características fundamentais dessa figura é que ela preserva certa autonomia em relação à fábula e à ação (Ubersfeld, 1996, p. 137-40). 
cas capazes de esboçar uma mimese inédita. $\mathrm{Na}$ preservação das diferenças, alegoria e naturalismo, sagrado e profano, cena e texto, Antonio
Araújo e Fernando Bonassi convivem em celas paralelas no Presídio do Hipódromo, onde Apocalipse 1, 11 estreou no princípio do ano 2000.

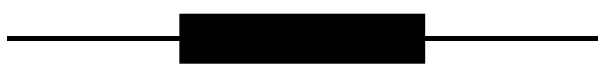

\section{Referências bibliográficas}

BARTHES, R. Essais critiques. Paris, Seuil, 1964.

BENJAMIN, W. "Qu'est-ce que le théâtre épique? Première version”. In: Essais sur Bertolt Brecht. Trad. Paul Laveau. Paris, Maspero, 1969.

BONASSI, F. O Apocalipse de João (primeira versão).

FÉRAL, J. "Le texte spectaculaire: la scène et son texte”. Degrés 97-98-99: 1-21, 1999.

HEUVEL, M.V. Performing drama / dramatizing performance. Ann Arbor, The University of Michigan Press, 1993.

JAMESON, F. Pós-Modernismo. A lógica cultural do capitalismo tardio. Trad. Maria Elisa Cevasco. São Paulo, Ática, 1996.

LEHMANN, H-T. “Theater der Blicke. Zu Heiner Müllers 'Bildbeschreibung”. Dramatik der D.D.R., ed. Ubrich Profitlich, Suhrkamp, apud Patrice Pavis. Le théatre au croisement des cultures. p. 99

MAURIN, F. Robert Wilson. Le temps pour voir, l'espace pour écouter. Paris, Actes Sud/Académie Expérimentale des théâtres, 1998.

NETO, DIONISIO. Opus Profundum. Texto inédito. 1996.

PAVIS, P. “Towards a semiology of the mise en scène”. In: Languages of the stage. Nova York, Performing Arts Journal Publications, 1982.

"Malaise dans la civilization: la réprésentation de la catastrophe dans le théâtre franco-allemand contemporain". In: Le théâtre au croisement des cultures. Paris, José Corti, 1990.

"Synthese premature ou Fermeture provisoire pour cause d'inventaire de fin de siècle". Texto da conferência realizada em Madri em 26 de novembro de 1998, no colóquio "Encuentro internacional sobre el autor teatral y siglo XX".

PEIXOTO, F. “Quando a crítica se transforma em grito”. In: Teatro de Heiner Müller. São Paulo, Hucitec, 1987.

RYNGAERT, J-P. Ler o teatro contemporâneo. Trad. Andréa Stahel M. da Silva. São Paulo, Martins Fontes, 1998.

SÁ, Nelson de. "Sob o tiroteio de palavras e descrença". In: Diversidade. Um guia para o teatro dos anos 90. São Paulo, Hucitec, 1998.

SCHECHNER, R. Performance theory. London, Routledge, 1988.

. "Training interculturally" In: BARBA. E. e SAVARESE. N. A Dictionary of theatre anthropology. London, Routledge, 1991.

UBERSFELD, A. “La scène et le texte”. In: L'école du spectateur. Paris, Ed. Sociales, 1981.

Lire le théatre III. Le dialogue de théâtre. Paris, Belin, 1996. 
VELTRUSKÝ, J. "Dramatic text as a component of theatre". In: MATEJKA, L. e TITUNIK, I. R. (eds.). Semiotics of art, Prague School Contributions. Cambrigne, MIT Press, 1976.

VINAVER, M. Écritures dramatiques. Paris, Actes Sud, 1993.

WATT, S. Postmodern drama. Reading the contemporary stage. The University of Michigan Press, 1998.

WILLIAMS, R. El teatro de Ibsen a Brecht. Trad. José M. Álvarez. Barcelona, Península, 1975. 